Historic, Archive Document

Do not assume content reflects current scientific knowledge, policies, or practices. 



\section{PRICE LIST FOR SPRING OF 1927}<smiles>C[O+]C</smiles>

\section{THE LINN COUNTY}

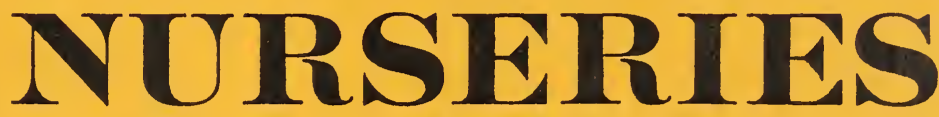

\section{SNYDER BROS., Inc.}

\section{Center Point, Iowa}

ESTABISHED 1895

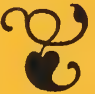

\section{GROWERS OF}

EVERGREFNS

ORNAMENTAT TREES AND PLANTS

FRUIT TREES

NUT TREES 


\section{FOREWORD}

LOCATION. Our nurseries are located on Primary Road No. 11, just south of the C., R. I. \& P. and W., C. F. \& N. Stations, so are easily reached by rail or motor ear. Our orchards and testing grounds are on Primary Road No. 11, two miles south. east of the nursery.

PACKING FACILITIES. These consist of a cellar and clay block building 100 feet square. Boxes and bales are well papered and the roots protected with moist packing. Evergreens and large trees are dug only as they are sent out.

GUARANTEE. We exercise great care to keep our varieties true to name and are ready at any time, upon satisfactory proof, to replace any stock that may prove untrue, or to refund the amount paid for the same, but it is mutually agreed that we are not to be held liable for any amount greater than the original price paid for the stock.

CONDITIONS. All orders are accepted on condition that they shall be void should any injury befall the stock from hail, frost, fire, or other causes beyond our control. Deliveries are subject to delay by bad weather, bad roads, strikes, accidents, embargoes and causes beyond our control.

TERMS are cash on or before the delivery of the stock, unless previously otherwise agreed upon.

CLAIMS for errors or shortage must be made immediately upon the receipt of the stock.

PRICES given are for the stock, properly packed and delivered at the Nursery, the stations here, or at nearby towns in case we are making a general delivery there. Small plants will be sent by parcel post within the second zone or the third zone if not too heavy.

VISITORS WELCOME. We are always pleased to show visitors about the place if time to do so is available. During the packing and shipping season it is not always possible to give visitors the time we would like to. Trees may be selected and tagged at any time of year for delivery at the proper time. Evergreens over nine feet high should be tagged before freezing weather so a frozen ball of earth can be moved with them.

VARIETIES NOT LISTED IN THIS CATALOG. We have some trees and plants of many kinds not listed in this catalog. If you do not see what you want, write us. 


\section{APPLES}

Apple trees should be planted $30 \times 30$ feet apart. They respond to good cultiration and care as freely as does corn or any other crop. Our trees are graded according to the standard rules of grading. The 5 and $6 \mathrm{ft}$. size caliper $\frac{11}{16}$ in. and up; the other sizes $5 / 8$ to $\frac{11}{16}$ in. and $1 / 2$ to $\frac{5}{8}$ in., respectivels. Many rarieties will run considerably taller than rated.

The following is a list of the main varieties of apples we have this spring, arranged approximately in the order of their ripening:

\section{EARIY VARIETIES}

Liveland (Lowland Raspberry)

Summer Pear

Yellow Transparent
Duchess (Oldenburg)

Benoni

Drer

\section{FAIL VARIETIES}

Nichner Strawberry

University

Bailey Sweet

McIntosh

Delicious

Jonathan

Grimes (Golden)

King David

Banana (Winter)

Golden Russet

Sheriff

Isherwood

Paradise W. Sweet

Hrslop

Whitney (No. 20)

Tirginia

\section{Anism}

Wealthy

\section{WINTER VARIETIES}

Windsor

Iowa Blush

Tolman Sweet

Torthern Spy

N. W. Greening

Tragoner

Stayman (Winesap)

Roman Stem

Cotta

\section{CRAB APPIES}

Transcendant

Sweet Russet

PRICES of standard Apple and Crab Apple:

5 to 6 feet

4 to 5 feet

3 to 4 feet

-

Snow (Fameuse)

Wolf River

Longfield

\author{
Allen's Choice \\ Salome \\ Black Annette \\ Mammoth Black Twig \\ Gano \\ Black Ben Daris \\ Ben Davis \\ Nelson Sweet \\ Malinda \\ Rall's (Janet or Geniton)
}

Martha

Wild Red

White Arctic

DWARF APPIES

$\begin{array}{lrr}\text { Delicious } & \text { Wealthy } & \text { Fellow Transparent } \\ \text { PRICES of Dwarf Apple: } & \text { Each } & \text { Per } 10 \\ 4 \text { to } 5 \text { feet } & \$ 1.00 & \$ 9.00\end{array}$

\section{PEACHES}

Peaches in central Iowa should be planted where thes will have as much protection as possible.

Leading varieties-Champion, Bokara, and Elberta.

\section{PRICES-}

Budded trees

Bailey Seedlings

The hardiest of all peaches.
Each $\$ 0.90$

.75

.60

$\begin{array}{lrr} & \text { Each } & \text { Per } 10 \\ 4 \text { to } 5 \mathrm{ft.} & \$ 0.60 & \$ 5.00 \\ 3 \text { to } 4 \mathrm{ft} & .45 & 4.00 \\ 3 \text { to } 4 \text { ft. } & .20 & 1.50 \\ 4 \text { to } 5 \text { ft. } & .40 & 3.50 \\ 5 \text { to } 6 \mathrm{ft} . & .50 & 4.50\end{array}$

Per 10

$\$ 8.00$

6.50

4.50

Per 100

$\$ 75.00$

60.00

40.00 


\section{PEARS}

More than one variety should be planted to insure pollination. The Standard or large growing trees should be spaced 18 to $20 \mathrm{ft}$. apart; the Dwarfs, $10 \mathrm{ft}$.
Garber
Flemish Beauty
Seckel
Kieffer
Clapp's Favorite
Willer
Longworth
Bartlett
Tyson

All Standard Pears:

\begin{tabular}{|c|c|}
\hline 5 to 6 feet & $\$ 1.25$ \\
\hline 4 to 5 feet & 1.00 \\
\hline 3 to 4 feet & .75 \\
\hline
\end{tabular}

DWARF PEARS are grafted on Quince roots, which dwarf and bring them into bearing earlier. The following varieties in the 4 to 5 and 3 to 4 foot sizes only:
Bartlett
Seckel
Duchess
Kieffer
Anjou
Clapp's Favorite

Flemish Beauty

All Dwarf Pears:

4 to 5 feet

3 to 4 feet

Each

$\$ 1.00$

Per 10

$\$ 9.00$

.75

7.00

Dyehouse

Early Richmond

Montmoreney

\section{CHERRIES}

(In order of ripening)

Ostheime
Baldwin
Yellow Glass
Wrage

English Morello

Early Richmond and Montmorency are the most dependable and the most planted. Yellow Glass is a true, sweet cherry and is more tender than the others. Wragg and English Morello are very late and very dark in color.
Above varieties except Yellow Glass-
5 to 6 feet
Each
$\$ 1.25$
4 to 5 feet
1.00
3 to 4 feet
.70
Per 10
$\$ 10.00$
9.00
6.00

Yellow Glass 25c each higher on each grade.

\section{PLUMS-Standard Varieties}

\section{Abundance \\ Burbank \\ Compass \\ Communia \\ Damson \\ Desoto \\ Fellenburg}

German Prune
Gold
Hanska
Lombard
Miner
Omaha
Opata

Sapa

Surprise

Ter'y

Toka

Wachampa

Waneta

Terry, Surprise, and Desoto are all pure American varieties of splendid quality for all purposes, and we believe most dependable of all for the far North.

Abundance and Burbank are Japanese varieties, which are much prized by some, but usually overbear and are short-lived bere.

Sapa, Opata, and Wachampa are all hybrids of the western Sand Cherry produced by Professor Hansen, and all make very crooked trees. Sapa is of medium size, has purplish flesh, a very small pit, and is very fine for eanning. Wachampa is very similar to Sapa except the flesh is a lighter color. Opata has green flesh and is very early, but not especially good for cooking.

Hanska and Toka are also hybrids produced by Professor Hansen and generally included in the group known as the Hansen Hybrids. They are crosses of the American Plum and Prunus Simoni. Both varieties are very straight, symmetrical, up- 
right trees. The fruit is bright red, of good size, and has a very pronounced apricot fragrance and flavor. Many people think them the best plums in our whole list.

Omaha and Waneta are very productive hybrids, more especially valued for eating from the tree, for which purpose there are few varieties equal to Omaha.

Communia, Damson, German Prune, Fellenburg or Italian Prune, and Lombard are all European varieties often spoken of as blue plums.

$\begin{array}{rrrr}\text { PRICES of above varieties- } & \text { Each } & \text { Per } 10 & \text { Per } 100 \\ 5 \text { to } 6 \text { feet } & \$ 1.25 & \$ 10.00 & \$ 85.00 \\ 4 \text { to } 5 \text { feet } & 1.00 & 8.00 & 70.00 \\ 3 \text { to } 4 \text { feet } & .75 & 6.00 & 50.00\end{array}$

\section{PLUMS-New or Rare Varieties}

Beatty

Bohemian Prune

Hennepin

Mary

Beatty is a local variety. It is very much prized by people who know it. The fruit is long, yellow and red in color and rery excellent for all purposes. The tree grows in an inverted pyramidal form.

Wyckoff is a variety of medium size and light red color with a very thin skin and especially fine for canning, no other variety excelling it for this purpose.

Mary is a European plum belonging to the Green Gage type. It has proved very productive and the plums are perhaps the sweetest of any variety we have. They are a clear green color, which they hold in canning.

Bohemian Prune is one of the hardiest European varieties and the best real prune we have tested so far.

Hennepin, Red Wing, Monitor, Underwood, and Winona are a new group of plums which recently originated at the Minnesota State Fruit Breeding Farm. They are all large or very large and excellent varieties.

PRICES of above varieties-

Each

$\$ 1.25$

5 to 6 feet

1.00

3 to 4 feet

.75
Per 10

$\$ 12.50$

10.00

7.50

\section{GRAPES \\ (In order of ripening)}

Beta, black

Hungarian, black

Moore Early, black

Diamond (Moore's), white

Wyoming, red
Elvira, white

Worden, black

Dela.ware, red

Lucile, red

Niagara, white
Lutie, red

Concord, black

Woodruff, red

Agawan, red

Beta, Hungarian and Elvira are small grapes, but very hardy and well suited for arbors and pergolas.

Concord is the best slipping variety and predominates in commercial plantings.

Worden and Moore Early are larger and sweeter than Concord and should be included in the home vineyard.

\begin{tabular}{|c|c|c|c|}
\hline PRICES- & Each & Per 10 & Per 100 \\
\hline Concord-1 year & $\$ 0.20$ & $\$ 1.50$ & $\$ 10.00$ \\
\hline 2 year & .25 & 2.00 & 15.0 \\
\hline Other varieties-1 year & 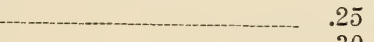 & 2.00 & 15.00 \\
\hline 2 year & 30 & 2.50 & $22 . \overline{2}$ \\
\hline
\end{tabular}




\section{CURRANTS}

lowa.

Currants eannot be sent across the quarantine line, which is the western line of

Victoria

Wilder

White Grape

2-year Bushes-

Perfection

Other varieties
Cherry

Perfection
Diploma

Fay (Fay's Prolific)
Each $\$ 0.40$

.30

$$
\begin{array}{r}
\text { Per } 10 \\
\$ 3.50 \\
2.50
\end{array}
$$

Per 100

$\$ 30.00$

17.50

\section{GOOSEBERRIES}

Subject to the same quarantine as Currants.

Champion

Pearl

Carrie

Downing

PRICES-2-year plants

$30 \mathrm{e}$ each

$\$ 2.50$ per 10

\section{JUNEBERRIES (Serviceberry, Shadbush)}

Juneberry bushes are highly ormamental at all seasons of the year as well as being valuable for their fruit, which is much liked by the birds and attracts them from other berries and the cherries. Planted in a hedge row they will make an oval hedge 6 to 8 feet high and about that width.

PRICES-For transplants-

Each

Per 10

12 to 18 inch bushes $\$ 0.20$

18 to 24 inch bushes

$\$ 1.50$

2 to 3 foot bushes

2.00

3 to 4 foot bushes

3.00

4.00

\section{RASPBERRIES}

The purple and black varieties grow from tips, red ones from suckers. For home use the purple caps will produce more fruit than the others.

Cumberland is the most planted of the black eaps.

Latham is far the best and most profitable of the red varieties. Plant in hedge rows about two feet apart in the rows.

Columbian, purple

Cardinal, purple

Cumberland, black

PRICES-

Purple varieties and Latham

St. Regis, red everbearing

Haymaker, purple

Royal Purple, purple
King, red

Louden, red

Latham, red

Other varieties

Per 10 $\$ 0.75$
Per 100

$\$ 6.00$

3,00
Per 1,000

$\$ 50.00$

25.00

\section{BLACKBERRIES AND DEWBERRIES}

We have found the Snyder Blackberry the most dependable of many kinds tried and confine our growing to it. All the plants offered are root eutting plants; none are suckers from an old run-out patch.

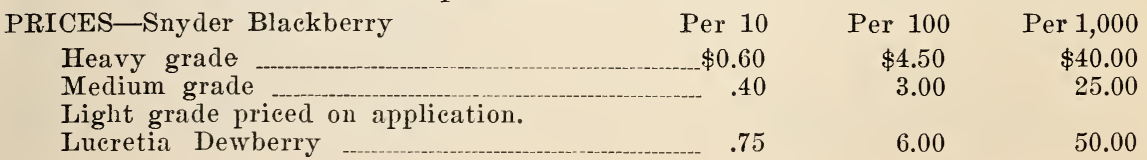




\section{STRAWBERRIES}

The Dunlap Strawberry succeeds so well under so many different conditions and is so good for all purposes that we adrise it as the best spring bearing rariety for general planting. Put out a new bed each rear in rows $3 \frac{1 / 2}{2}$ to 4 feet apart and 18 inches in the row.

The fall bearing Strawberries do best north of central Iowa, where if proper care is given and conditions are farorable, wonderful results are often obtained. They should be planted early in the spring on good, rich ground and a new patch planted each rear.

$\begin{array}{lrr}\text { PRICES- } & \text { Per } 100 & \text { Per } 1,000 \\ \text { Dunlap } & \$ 1.00 & \$ 9.00 \\ \text { Progressive, fall bearing } & 2.50 & 20.00\end{array}$

\section{ASPARAGUS}

This is one of the first ready to use and most wholesome of the spring regetables. Plant it along the fence and plant it by the hundred rather than by the dozen.

$\begin{array}{lrrr}\text { PRICES- } & \text { Per } 10 & \text { Per } 100 & \text { Per } 1,000 \\ \text { Two-year plants } & \$ 0.40 & \$ 2.50 & \$ 20.00\end{array}$

\section{RHUBARB}

Rhubarb, like Asparagus, should be planted where it need not be disturbed and will produce a great lot of wholesome food with the minimum amount of work. Heary clumps of it may be forced in the cellar in winter if they are dug in the fall and allowed to freeze hard before taking in.

$\begin{array}{lrrr}\text { PRICES- } & \text { Each } & \text { Per } 10 & \text { Per } 100 \\ \text { Two-year roots } & \$ 0.20 & \$ 1.50 & \$ 10.00 \\ \text { One-year roots } & .15 & 1.00 & 6.00\end{array}$

\section{EVERGREENS}

All the Evergreens we offer have been transplanted two or more times unless otherwise noted. They are always dug fresh as sent out. If the buyer comes to the Nursery after them, they can be lifted directly from the row to his truck and hare a minimum of exposure. If the roots of evergreens erer become thoroughly dry they cannot be revived as other trees can. Failure in transplanting them is largely due to allowing them to become dry while planting, to not packing good, mellow, moist soil very firmly around the roots, or to not properly conserving moisture about them through the summer by frequent shallow eultiration and by mulching.

SPACING. Plant Pines or Spruces 7 to 8 feet apart for single row windbreaks: and 10 to 12 feet apart for double rows. For hedges plant 18 to 24 inches apart, depending on size.

SoILs. Plant Pines on dry or well drained soil. The Bull Pine will do well on very gravelly soil. In places where it is quite wet at times Spruce will be better, and in rery wet places Arborvitae is the best. 


\section{EVERGREENS FOR WINDBREAKS AND HEDGES}

Prices in this section do not include Ball and Burlap; if wanted that way, the expense of it must be added.

ARBORVITAE-American, Thuja occidentalis

A native of the north, preferring a moist soil. All large sizes are three times transplanted.

PINE-Bull, Pinus Ponderosa, Western Yellow Pine

A native of the Black Hills, with very long needles and thick, stout branches, which are not broken by heavy sleet or severe storms. Extremely hardy and drouth-resistant.

PINE-Scotch, Pinus sylvestris Native to Northern Europe.

PINE-White, Pinus strobus One of Iowa's few native conifers.

RED CEDAR_Juniperus virginiana Should not be planted near apple trees because of the Cedar Apple rust, otherwise very desirable.

$\begin{array}{rrrr}\text { Size } & \text { Each } & \text { Per 10 } & \text { Per 160 } \\ 12 \text { to } 15 \mathrm{in} . & \$ 0.40 & \$ 3.50 & \$ 30.00 \\ 2 \text { to } 3 \mathrm{ft} . & .75 & 7.00 & 60.00 \\ 3 \text { to } 4 \mathrm{ft} . & 1.00 & 9.00 & 75.00 \\ 4 \text { to } 5 \mathrm{ft} . & 1.25 & 12.00 & 100.00 \\ 5 \text { to } 6 \mathrm{ft} . & 1.50 & 14.00 & 125.00 \\ & & & \\ 18 \text { to } 24 \mathrm{in} . & .50 & 4.00 & 35.00 \\ 2 \text { to } 3 \mathrm{ft} & .60 & 5.00 & 45.00 \\ 3 \text { to } 4 \mathrm{ft} . & .70 & 6.00 & 55.00 \\ 4 \text { to } 5 \mathrm{ft} & .85 & 8.00 & 75.00 \\ 5 \text { to } 6 \mathrm{ft} . & 1.00 & 9.50 & 90.00\end{array}$

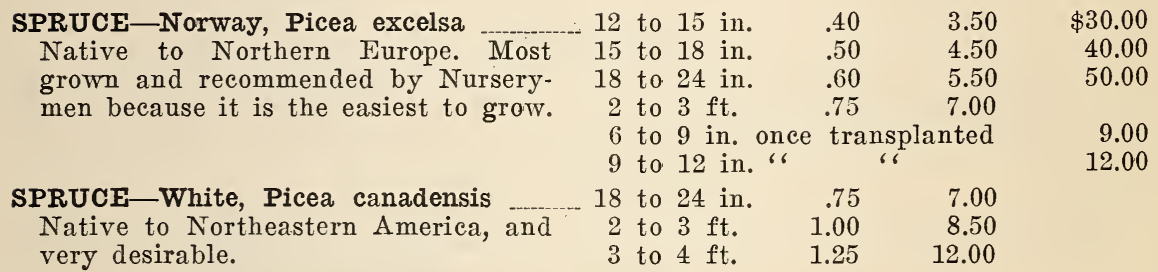

SPECIMEN EVERGREENS-For Iandscape Planting

(Prices in this section include ball and burlap)

The following are well developed trees which have been several times transplanted and are dug with a solid ball of earth securely burlapped and bound. They are much heavier to handle, but easier to plant and more certain to grow. In planting do not remove the burlap. Arter the tree is in place and hole partly filled to hold it, cut the burlap loose around the top and pour in plenty of water. Large trees over 8 feet should be ordered before hard freezing so they can be mulched for digging and the ball of dirt frozen solidly before moving.

$\begin{array}{lrrr} & \text { Size } & \text { Each } & \text { Per } 10 \\ \text { ARBORVITAE-American } & 15 \text { to } 18 \mathrm{in.} & \$ 0.75 & \$ 7.00 \\ & 18 \text { to } 24 \mathrm{in} . & 1.00 & 9.00 \\ & 2 \text { to } 3 \mathrm{ft} . & 1.50 & 12.00 \\ & 3 \text { to } 4 \mathrm{ft} . & 2.00 & 17.50 \\ & 4 \text { to } 5 \mathrm{ft} . & 2.50 & 20.00 \\ \text { Globe } & 5 \text { to } 6 \mathrm{ft} . & 3.00 & 25.00 \\ \text { A dwarf form which makes compact } & 10 \text { to } 12 \mathrm{in} . & \$ 1.00 & \\ \text { globes without trimming. } & 12 \text { to } 15 \mathrm{in} . & 1.50 & \\ & 18 \text { to } 24 \mathrm{in.} & 2.50 \\ & 2 \text { to } 21 / 2 \mathrm{ft} . & 3.00\end{array}$


SPECIMEN EVERGREENS-Contintied

$\begin{array}{lrr}\text { Hovey's Golden } & 15 \text { to } 18 \mathrm{in} . & 1.50 \\ & 18 \text { to } 24 \mathrm{in.} & 2.00 \\ 2 \text { to } 3 \mathrm{ft} . & 3.00 \\ \text { Pyramidal } & 9 \text { to } 12 \mathrm{in} . & .75 \\ & 12 \text { to } 15 \mathrm{in.} & 1.00 \\ 15 \text { to } 18 \mathrm{in} . & 1.50 \\ 18 \text { to } 24 \mathrm{in} . & 2.25 \\ 2 \text { to } 21 / 2 \mathrm{ft} . & 3.00 \\ 21 / 2 \text { to } 3 \mathrm{ft} . & 4.00 \\ & 3 \text { to } 3 \frac{1}{2} \mathrm{ft} . & 5.00\end{array}$

ARBORVITAE-Siberian 12 to $15 \mathrm{in.} \quad 1.50$

The hardiest of all the arborvitae, 15 to $18 \mathrm{in.} \quad 2.00$

rery compact, conical in form and 18 to $24 \mathrm{in.} 2.50$

with dense dark green foliage. $\quad 2$ to $2 \frac{1}{2} \mathrm{ft}$. 3.50

$21 / 2$ to $3 \mathrm{ft}$. $\quad 4.50$

6 to $7 \mathrm{ft}$. $\quad 12.00$

FIR-Balsam

4 to $5 \mathrm{ft}$.

3.00

A native of Iowa and Northeast. It 5 to $6 \mathrm{ft}$. 3.50

should have moist soil. The leaves and 6 to $7 \mathrm{ft}$. 4.00

branches are delightfully fragrant.

$\begin{array}{lll}\text { Concolor } & 15 \text { to } 18 \mathrm{in.} & 4.00 \\ \text { Larger sizes quoted on application. } & 18 \text { to } 24 \mathrm{in.} & 5.00 \\ 2 \text { to } 3 \mathrm{ft} . & 6.00\end{array}$

Douglas

2 to $2 \frac{1}{2} \mathrm{ft}$.

Also known as Douglas Spruce. $\quad 21 / 2$ to $3 \mathrm{ft}$.

3.00

4.00

3 to $4 \mathrm{ft}$.

5.00

HEMLOCK

12 to $18 \mathrm{in}$.

1.50

Native to northeastern United States.

18 to $24 \mathrm{in}$.

2.50

A slow growing, graceful tree with 2 to $2 \frac{1}{2} \mathrm{ft}$.

3.50

short, flat needles, bright green above, $2 \frac{1}{2}$ to $3 \mathrm{ft}$.

4.50

silvery beneath.

3 to $3 \frac{1}{2} \mathrm{ft}$.

6.00

7.00

4 to 5 it.

8.00

5 to $6 \mathrm{ft}$.

6 to $7 \mathrm{ft}$.

9.00

10.00

\section{JUNIPER-Pfitzer's}

15 to $18 \mathrm{in}$

3.50

A rariety of the Chinese Juniper. The

foliage is bluish green and the

18 to $2 t$ in.

5.00

branches grow out horizontally from

2 to $3 \mathrm{ft}$.

6.00

the stem, which gives the tree an individuality of its own. Sizes apply to width rather than height.

Savin 9 to 12 in. A bushy little tree with semi-erect 12 to $15 \mathrm{in}$. branches and clear green foliage. It is excellent for foundation plantings 15 to $18 \mathrm{in}$. and in rockeries or dry sunny places. 
SPECIMEN EVERGREENS-Continued

LARCH-European 2 to $3 \mathrm{ft}$.

A conifer, but not an evergreen. $\quad 3$ to $4 \mathrm{ft}$.

s to 4 ft.

2.00

6 to $7 \mathrm{ft}$.

5.00

PINE-Bull

2 to 3 ft.

2.00

Larger sizes quoted upon application.

3 to $4 \mathrm{ft}$.

2.50

4 to $5 \mathrm{ft.}$.

5 to $6 \mathrm{ft}$.

3.50

4.50

6 to $7 \mathrm{ft}$.

6.00

PINE-Mugho

9 to 12 in.

1.50

Dwarf Mountain Pine. This makes a

18 to $24 \mathrm{in}$.

5.00

compact dome-shaped bush broader

than high. Sizes apply to width rather

$21 / 2$ to $3 \mathrm{ft}$.

3 to $4 \mathrm{ft}$.

7.50

10.00

Red

5 to $6 \mathrm{ft}$.

4.00

A native of northern Wisconsin.

6 to $7 \mathrm{ft}$.

5.00

Needles long and soft and a very

pretty green. One of the most beauti-

ful pines.

Scotch

3 to $4 \mathrm{ft}$.

3.00

White

3 to $4 \mathrm{ft}$.

2.50

Sizes up to $15 \mathrm{ft}$. quoted on applica-

tion.

4 to $5 \mathrm{ft}$.

5 to $6 \mathrm{ft}$.

3.50

4.50

6 to $7 \mathrm{ft}$.

6.00

SPRUCE-Black Hills

12 to $15 \mathrm{in}$.

1.25

10.00

A native of the Black Hills. It does

15 to $18 \mathrm{in.}$

1.50

12.50

very well over a wide range and makes

18 to $24 \mathrm{in}$.

the finest specimens of all Spruce un-

less it is the Colorado Blue.

\section{Colorado Blue}

2 to $21 / 2 \mathrm{ft}$.

17.50

2.00

22.50

$21 / 2$ to $3 \mathrm{ft}$.

27.50

3 to $4 \mathrm{ft}$.

37.50

4 to $5 \mathrm{ft}$.

3.00

4.00

45.00

5 to $6 \mathrm{ft}$.

5.00

60.00

6 to $7 \mathrm{ft}$.

75.00

A native of Colorado. It varies from clear green to glistening silvery blue. They are slow growing and very compact, making the finest lawn specimens.

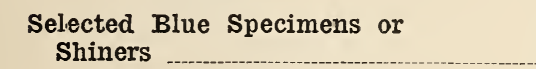

15 to $18 \mathrm{in.}$

18 to $24 \mathrm{in.}$

2 to $21 / 2 \mathrm{ft}$.

$21 / 2$ to $3 \mathrm{ft}$.

3 to $4 \mathrm{ft}$.

4 to $5 \mathrm{ft}$.

Green Specimens
5.00

6.00

7.50

10.00

12.50

15.00

2.50

3.00

3.50

4.50

6.00

8.00

2.50

3.00

4.50
18.50

25.00

30.00

35.00

45.00

Norway

3 to $4 \mathrm{ft}$.

Sizes up to $18 \mathrm{ft}$. quoted on application. 4 to $5 \mathrm{ft}$.

5 to $6 \mathrm{ft}$. 


\section{SPECIMEN EVERGREENS-Continued}

$\begin{array}{lrrr}\text { White, American White Spruce } & 2 \text { to } 3 \mathrm{ft.} & 2.00 & 18.00 \\ & 3 \text { to } 4 \mathrm{ft} . & 3.00 & 25.00 \\ & 4 \text { to } 5 \mathrm{ft} . & 5.00 & 35.00 \\ & 5 \text { to } 6 \mathrm{ft} & 5.00 & 45.00 \\ 6 \text { to } 7 \mathrm{ft} . & 6.50 & 55.00 \\ 7 \text { to } 8 \mathrm{ft} . & 8.00 & 70.00 \\ \text { YEW-Taxus canandensis } & 9 \text { to } 12 \mathrm{inh} & 1.00 & \\ \text { Canada Yew. } & 12 \text { to } 15 \mathrm{in.} & 1.50\end{array}$

\section{SHADE AND ORNAMENTAL TREES}

We have numerous trees, which are too large for boxing and shipping, which we will quote on application. They consist of American Elm up to 6 inches in diameter, Burr Oak up to 4 inches, Ash up to $2 \frac{1}{2}$ inches, and Maples up to $4 \frac{1}{2}$ inches.

\begin{tabular}{|c|c|c|c|}
\hline AILANTHUS, Tree of Heaven & \begin{tabular}{l}
\multicolumn{3}{l}{ Size } \\
4 to $5 \mathrm{ft}$. \\
5 to $6 \mathrm{ft}$. \\
6 to $8 \mathrm{ft}$.
\end{tabular} & $\begin{array}{l}\text { Each } \\
\$ 0.75 \\
1.00 \\
1.50\end{array}$ & $\begin{array}{r}\text { Per } 10 \\
\$ 7.00 \\
9.00 \\
12.00\end{array}$ \\
\hline ASH-American & $\begin{array}{r}7 \text { to } 8 \mathrm{ft} . \\
8 \text { to } 10 \mathrm{ft} . \\
10 \text { to } 12 \mathrm{ft} .\end{array}$ & $\begin{array}{l}1.00 \\
1.50 \\
2.00\end{array}$ & $\begin{array}{l}10.00 \\
14.00 \\
18.00\end{array}$ \\
\hline BIRCH-European White & $\begin{array}{l}5 \text { to } 6 \mathrm{ft} . \\
6 \text { to } 8 \mathrm{ft} \text {. }\end{array}$ & $\begin{array}{l}1.75 \\
2.50\end{array}$ & $\begin{array}{l}16.00 \\
22.00\end{array}$ \\
\hline CATALPA-Speciosa, Western Catalpa & $\begin{array}{l}5 \text { to } 6 \mathrm{ft} \text {. } \\
6 \text { to } 8 \mathrm{ft} .\end{array}$ & $\begin{array}{r}.90 \\
1.25\end{array}$ & $\begin{array}{r}7.50 \\
10.00\end{array}$ \\
\hline Bungei-2-year heads & $\begin{array}{l}5 \mathrm{ft} . \\
6 \mathrm{ft} .\end{array}$ & $\begin{array}{l}2.50 \\
3.00\end{array}$ & \\
\hline CRAB_-Bechtel's Double Flowering & $\begin{array}{r}18 \text { to } 24 \mathrm{in} . \\
2 \text { to } 3 \mathrm{ft} \text {. } \\
3 \text { to } 4 \mathrm{ft} \text {. } \\
4 \text { to } 5 \mathrm{ft} \text {. }\end{array}$ & $\begin{array}{r}.75 \\
1.25 \\
1.75 \\
2.50\end{array}$ & $\begin{array}{r}6.00 \\
10.00 \\
12.50 \\
20.00\end{array}$ \\
\hline Carmine, atrosanguinea & $\begin{array}{r}18 \text { to } 24 \mathrm{in} . \\
2 \text { to } 3 \mathrm{ft} \text {. } \\
5 \text { to } 6 \mathrm{ft} \text {. }\end{array}$ & $\begin{array}{r}.75 \\
1.00 \\
2.00\end{array}$ & \\
\hline Hoppa-Hansen's Red Siberian & $\begin{array}{l}3 \text { to } 4 \mathrm{ft} \text {. } \\
4 \text { to } 5 \mathrm{ft} \text {. }\end{array}$ & $\begin{array}{l}1.25 \\
1.50\end{array}$ & \\
\hline Parkman .......... & $\begin{array}{l}3 \text { to } 4 \mathrm{ft} \text {. } \\
4 \text { to } 5 \mathrm{ft} \text {. }\end{array}$ & $\begin{array}{l}2.00 \\
2.50\end{array}$ & \\
\hline Redvein, Niedzwetzkyana & $\begin{aligned} 18 & \text { to } 24 \mathrm{in} . \\
2 & \text { to } 3 \mathrm{ft} \text {. }\end{aligned}$ & $\begin{array}{r}.75 \\
1.00\end{array}$ & \\
\hline ELM-American White & $\begin{array}{r}5 \text { to } 6 \mathrm{ft} . \\
6 \text { to } 7 \mathrm{ft} . \\
7 \text { to } 8 \mathrm{ft} . \\
8 \text { to } 10 \mathrm{ft} . \\
10 \text { to } 12 \mathrm{ft} .\end{array}$ & $\begin{array}{r}.60 \\
.90 \\
1.00 \\
1.50 \\
2.00\end{array}$ & $\begin{array}{r}5.00 \\
7.50 \\
8.50 \\
12.50 \\
17.50\end{array}$ \\
\hline Moline-1 year & $\begin{array}{l}5 \text { to } 6 \mathrm{ft} . \\
6 \text { to } 8 \mathrm{ft} . \\
8 \text { to } 10 \mathrm{ft} \text {. }\end{array}$ & $\begin{array}{l}1.25 \\
2.50 \\
3.00\end{array}$ & 10.00 \\
\hline Weeping _ _ & 2-year heads & 3.00 & \\
\hline
\end{tabular}


SHADE AND ORNAMENTAL TREES-Continued

GINKGO, Maiden Hair Tree 4 to $5 \mathrm{ft}$.

2.00

HACKBERRY

5 to $6 \mathrm{ft}$.

1.25

6 to $7 \mathrm{ft}$.

7 to $8 \mathrm{ft}$.

8 to $10 \mathrm{ft}$.

1.50

2.00

2.50

HICKORY-Shagbark

4 to $5 \mathrm{ft}$.

2.50

5 to $6 \mathrm{ft}$.

3.00

3 to $4 \mathrm{ft}$.

4 to $5 \mathrm{ft}$.

.60

.75

10.00

14.00

18.00

HOP TREE

4 to $5 \mathrm{ft}$.

2.50

HORSE CHESTNUT

5 to $6 \mathrm{ft}$.

3.00

KENTUCKY COFFEE TREE

2 to $3 \mathrm{ft}$.

3 to $4 \mathrm{ft}$.

.75

1.00

LINDEN-American

5 to $6 \mathrm{ft}$.

6 to $8 \mathrm{ft}$.

1.50

2.00

8 to $10 \mathrm{ft}$.

2.50

12.50

5 to $6 \mathrm{ft}$.

.75

6 to $8 \mathrm{ft}$.

1.25

22.00

LoCUST-Honey, Thornless

5 to $6 \mathrm{ft}$.

1.50

22.00

25.00

MAPLE-Hard or Sugar

6 to $7 \mathrm{ft}$.

7 to $8 \mathrm{ft}$.

8 to $10 \mathrm{ft}$.

2.00

5.00

6.00

5 to $6 \mathrm{ft}$.

6 to $8 \mathrm{ft}$.

Norway

8 to $10 \mathrm{ft}$.

10 to $12 \mathrm{ft}$.

2.50

3.00

18.00

22.00

7.00

10.00

2.25

3.00

4.00

5.00

Tartarian, Ginala

2 to $3 \mathrm{ft}$.

3 to $4 \mathrm{ft}$.

.75

4 to $5 \mathrm{ft}$.

1.25

2.00

Schwedler's Purple Leaved

5 to $6 \mathrm{ft}$.

3.50

6 to $8 \mathrm{ft}$.

4.00

Weir's Cut Leaved Weeping

5 to $6 \mathrm{ft}$.

1.50

6 to $8 \mathrm{ft}$.

14.00

17.50

22.00

28.00

20.00

28.00

37.50

MAY DAY TREE, Prunus padus

5 to $6 \mathrm{ft}$.

2.00

MOUNTAIN ASH-European

4 to $5 \mathrm{ft}$.

1.50

5 to $6 \mathrm{ft}$.

1.00

1.75

6 to $7 \mathrm{ft}$.

7 to $8 \mathrm{ft}$.

8 to $10 \mathrm{ft}$.

2.20

2.50

3.00

Oak Leaved

5 to $6 \mathrm{ft}$.

2.50

4 to $5 \mathrm{ft}$.

5 to $6 \mathrm{ft}$.

.50

.60

9.00

16.00

20.00

24.00

28.00

MULBERRY-Russian

2-year

5.00

Weeping

5 to $6 \mathrm{ft}$.

2.00

2.50

7 to $8 \mathrm{ft}$.

8 to $10 \mathrm{ft}$.

3.00

4.00

10 to $12 \mathrm{ft}$.

5.00

4.00

5.00 
SHADE AND ORNAMENTAL TREES-Continued

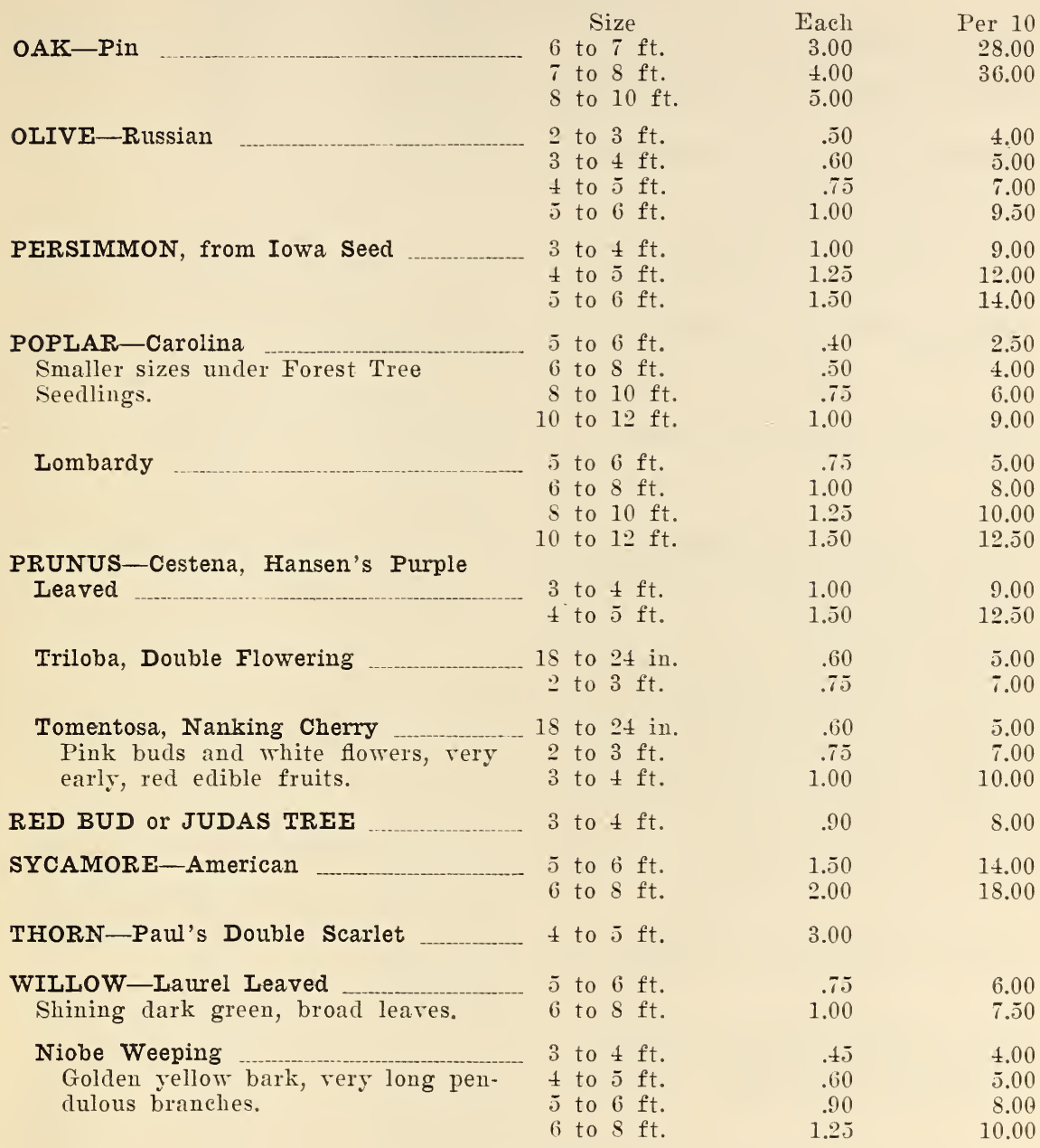

\section{SHRUBS}

In most cases both the common and botanical names are given. Preference is giren the botanical names except where the common namies are well fixed and much better known.

ALMONDS-Flowering Size

On Plum roots; pink or white. 18 to $24 \mathrm{in}$. 2 to $3 \mathrm{ft}$.

Each

Per 10

LTHEAS-Assorted 3 to $4 \mathrm{ft}$. $\$ 0.90$ $\$ 8.00$ 1.50 
SHRUBS-Continued

ARALIA pentaphylla

Size 18 to $24 \mathrm{in}$.

2 to $3 \mathrm{ft}$.

ARALIA spinosa, Devil's Walking Stick 3 to $4 \mathrm{ft}$.

Each

.40

Per 10

4 to $5 \mathrm{ft}$.

.50

1.00

1.25

ARONIA arbutifolia, Red Chokeberry

18 to $24 \mathrm{in}$.

.75

6.00

BARBERRY, Japanese

See under Hedge Plants.

BUTTERFIY BUSH, Buddleia

No. 1 plants.

.50

4.00

BUTTON BUSH, Cephalanthus

occidentalis

18 to 24 in.

Flowers in round balls.

2 to $3 \mathrm{ft}$.

3 to $4 \mathrm{ft}$.

4.00

.50

5.00

CARAGANA, Siberian Pea Tree

18 to $24 \mathrm{in.}$

Yellow flowers, early, tall.

2 to $3 \mathrm{ft}$.

2.00

.30

3.00

3 to $4 \mathrm{ft}$.

4 to $5 \mathrm{ft}$.

4.00

.50

.60

5.00

CLETHRA Alnifolia, Summersweet

18 to $24 \mathrm{in}$.

6.00

CORAI BERRY, Indian Currant, Sym-

phoricarpos vulgaris

18 to $24 \mathrm{in}$.

2.50

2 to $3 \mathrm{ft}$.

3.00

CORNUS, Dogwood

alternifolia, Pagoda Dogwood

18 to 24 in.

Very shade-enduring, tall.

2 to $3 \mathrm{ft}$.

5.00

7.00

elegantissima or variegated leaved

2 to $3 \mathrm{ft}$.

8.00

florida, large white flowering, tall

2 to $3 \mathrm{ft}$.

3 to $4 \mathrm{ft}$.

2.00

alba siberica, red twigged

18 to $24 \mathrm{in}$.

2 to $3 \mathrm{ft}$.

3 to $4 \mathrm{ft}$.

4 to $5 \mathrm{ft}$.

stolonifera lutea, yellow twigged

18 to 24 in.

2 to $3 \mathrm{ft}$.

3 to $4 \mathrm{ft}$.

mas, Cornelian Cherry, red berries

18 to $24 \mathrm{in}$.

COTONEASTER, Acutifolia, Peking

cotoneaster, black fruit

12 to $18 \mathrm{in.}$

18 to 24 in.

2 to $3 \mathrm{ft}$.

3 to $4 \mathrm{ft}$.

3.00

4.00

5.00

3.00

4.00

6.00

CRANBERRY, HIGHBUSH, Viburnum

opulis

12 to 18 in.

Red berries.

18 to $24 \mathrm{in}$.

2 to $3 \mathrm{ft}$.

3.50

.40

.50

.60

.75

4.50

5.00

7.00

.60

5.00

.75

CURRANTS, Ribes

2 to $3 \mathrm{ft}$.

3 to $4 \mathrm{ft}$.

1.00

7.00

Odoratum, fragrant, yellow

12 to 15 in.

Alpine, Mountain Currant

15 to $18 \mathrm{in.}$

18 to 24 in.

9.00

Dwarf, compact, shade-enduring.

No. 1 size

4.00

5.00

.50

4.00

.60

5.00

.75

7.00

DESMODIUM pendulifolium

2 to $3 \mathrm{ft}$.

.75

7.00

DEUTZIA crenata, purplish flowers

.50

4.50 
SHRUBS-Continued

\begin{tabular}{|c|c|c|c|}
\hline ELDER-Cut Leaved & $\begin{array}{l}\text { Size } \\
18 \text { to } 21 \mathrm{in} \text {. } \\
2 \text { to } 3 \mathrm{ft} \text {. } \\
3 \text { to } 1 \mathrm{ft} \text {. }\end{array}$ & $\begin{array}{r}\text { Each } \\
.40 \\
.50 \\
.60\end{array}$ & $\begin{array}{r}\text { Per } 10 \\
3.00 \\
4.00 \\
5.00\end{array}$ \\
\hline Golden & 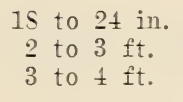 & $\begin{array}{l}.15 \\
.60 \\
.75\end{array}$ & $\begin{array}{l}4.00 \\
5.00 \\
7.00\end{array}$ \\
\hline Red Berried, pubens & 2 to $3 \mathrm{ft}$ & .75 & 700 \\
\hline $\begin{array}{l}\text { EUONYMUS alatus, Winged Wahoo } \\
\text { Broad, corky wings on twigs, red ber- } \\
\text { ries, brilliant autumn foliage. }\end{array}$ & $\begin{array}{l}12 \text { to } 18 \mathrm{in} \\
18 \text { to } 24 \mathrm{in} \\
2 \text { to } 3 \mathrm{ft} .\end{array}$ & $\begin{array}{l}.75 \\
1.00 \\
1.25\end{array}$ & \\
\hline EUONYMUS atropurpurea & 18 to $24 \mathrm{in}$ & .50 & \\
\hline $\begin{array}{l}\text { FORSYTHIA intermedia, Yellow Bells } \\
\text { Fellow flowers, very early. }\end{array}$ & 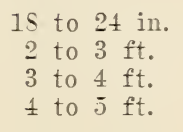 & $\begin{array}{l}.30 \\
.40 \\
.50 \\
.60\end{array}$ & $\begin{array}{l}2.00 \\
3.00 \\
4.00 \\
5.00\end{array}$ \\
\hline $\begin{array}{l}\text { HONEYSUCKLE, Lonicera } \\
\text { Bella Albida }\end{array}$ & $\begin{array}{l}15 \text { to } 24 \mathrm{in} \\
2 \text { to } 3 \mathrm{ft} \text {. } \\
3 \text { to } 4 \mathrm{ft} \text {. }\end{array}$ & $\begin{array}{l}.40 \\
.50 \\
.60\end{array}$ & $\begin{array}{l}3.00 \\
4.00 \\
5.00\end{array}$ \\
\hline Morrow's & $\begin{array}{l}15 \text { to } 24 \mathrm{in} \\
2 \text { to } 3 \mathrm{ft} \text {. } \\
3 \text { to } 4 \mathrm{ft} \text {. }\end{array}$ & $\begin{array}{l}.40 \\
.50 \\
.60\end{array}$ & $\begin{array}{l}3.00 \\
4.00 \\
5.00\end{array}$ \\
\hline Rupecht's & $\begin{array}{l}15 \text { to } 24 \mathrm{in} \\
2 \text { to } 3 \mathrm{ft} . \\
3 \text { to } 4 \mathrm{ft} .\end{array}$ & $\begin{array}{l}.40 \\
.50 \\
.60\end{array}$ & $\begin{array}{l}3.00 \\
4.00 \\
5.00\end{array}$ \\
\hline Tartarian, pink or write & $\begin{array}{l}15 \text { to } 24 \mathrm{in} \\
2 \text { to } 3 \mathrm{ft} . \\
3 \text { to } 4 \mathrm{ft}\end{array}$ & $\begin{array}{l}.40 \\
.50 \\
.60\end{array}$ & $\begin{array}{l}3.00 \\
4.00 \\
5.00\end{array}$ \\
\hline $\begin{array}{l}\text { HYDRANGEA } \\
\text { Arborescens, Hills of Snow }\end{array}$ & $\begin{array}{l}12 \text { to } 1 \mathrm{~s} \text { in. } \\
15 \text { to } 24 \mathrm{in.} \\
2 \text { to } 3 \mathrm{ft} \text {. }\end{array}$ & $\begin{array}{l}.45 \\
.60 \\
.75\end{array}$ & $\begin{array}{l}4.00 \\
5.00 \\
7.00\end{array}$ \\
\hline $\begin{array}{l}\text { Paniculata grandiflora } \\
\text { Hardy Hydrangea, bush form. }\end{array}$ & $\begin{array}{l}12 \text { to } 1 \mathrm{~s} \text { in. } \\
15 \text { to } 24 \mathrm{in} . \\
2 \text { to } 3 \mathrm{ft} \text {. } \\
3 \text { to } 4 \mathrm{ft} .\end{array}$ & $\begin{array}{r}.40 \\
.60 \\
.75 \\
1.00\end{array}$ & $\begin{array}{l}3.00 \\
5.00 \\
7.00 \\
9.00\end{array}$ \\
\hline Tree Form & $\begin{array}{l}3 \text { to } 4 \mathrm{ft} . \\
1 \text { to } 5 \mathrm{ft} \text {. }\end{array}$ & $\begin{array}{l}1.50 \\
2.00\end{array}$ & \\
\hline Paniculata praecox, Early Hỵdrangea__ & 2 to $3 \mathrm{ft}$ & 1.50 & \\
\hline $\begin{array}{l}\text { LILACS, Botanically Syringa } \\
\text { Common Purple and Common White. }\end{array}$ & $\begin{array}{l}15 \text { to } 21 \mathrm{in} \\
2 \text { to } 3 \mathrm{ft} \text {. } \\
3 \text { to } 1 \mathrm{ft} \text {. }\end{array}$ & $\begin{array}{l}.45 \\
.60 \\
.75\end{array}$ & $\begin{array}{l}4.00 \\
5.00 \\
7.00\end{array}$ \\
\hline $\begin{array}{l}\text { S. josikaea } \\
\text { Purplish dark glossy foliage, very late. }\end{array}$ & $\begin{array}{l}15 \text { to } 21 \mathrm{in} . \\
2 \text { to } 3 \mathrm{ft} \text {. } \\
3 \text { to } 1 \mathrm{ft} \text {. }\end{array}$ & $\begin{array}{r}.60 \\
.75 \\
1.00\end{array}$ & $\begin{array}{l}5.00 \\
7.00 \\
9.00\end{array}$ \\
\hline $\begin{array}{l}\text { S. microphylla } \\
\text { Pale lilac, small flower in June and } \\
\text { again in autumn. }\end{array}$ & 2 to $3 \mathrm{ft}$ & 2.00 & \\
\hline
\end{tabular}




\section{SHRUBS-Continued}

\begin{tabular}{|c|c|c|c|}
\hline $\begin{array}{l}\text { S. persica, Persian } \\
\text { Late, pale lilac, delicate foliage and } \\
\text { twigs. }\end{array}$ & $\begin{array}{l}\text { Size } \\
18 \text { to } 24 \mathrm{in} . \\
2 \text { to } 3 \mathrm{ft} . \\
3 \text { to } 4 \mathrm{ft} \text {. }\end{array}$ & $\begin{array}{r}\text { Each } \\
.60 \\
.75 \\
1.00\end{array}$ & $\begin{array}{r}\text { Per } 10 \\
5.00 \\
7.00 \\
9.00\end{array}$ \\
\hline $\begin{array}{l}\text { S. pubescens } \\
\text { Pale maure-pink, very fragrant, } \\
\text { large clusters, very early. }\end{array}$ & 2 to $3 \mathrm{ft}$. & 2.00 & \\
\hline $\begin{array}{l}\text { S. rothmagenesis, Rouen } \\
\text { Late, bluish lavender, fine twigs and } \\
\text { leaves. }\end{array}$ & $\begin{array}{l}18 \text { to } 24 \mathrm{in} . \\
2 \text { to } 3 \mathrm{ft} \text {. } \\
3 \text { to } 4 \mathrm{ft} \text {. }\end{array}$ & $\begin{array}{r}.60 \\
.75 \\
1.00\end{array}$ & \\
\hline
\end{tabular}

LILACS-Named Varieties, "French

Lilaes"

Belle de Nancy

18 to $24 \mathrm{in}$.

Double, rose and white.

2 to $3 \mathrm{ft}$.

1.25

Charles Tenth

18 to 24 in.

Reddish purple, single.

2 to $3 \mathrm{ft}$.

1.25

Jean Bart

18 to 24 in.

1.00

Double, rosy-carmine.

Lamartine-Single, rose mauve

2 to $3 \mathrm{ft}$.

3.00

Leon Ganbetta-Double, large, lilacrose

2 to $3 \mathrm{ft}$.

3.00

Louvain, Lovaniensis

18 to 24 in.

1.00

Single, silvery pink.

18 to $24 \mathrm{in.}$

1.00

Ludwig Spaeth

2 to $3 \mathrm{ft}$.

1.25

Mme. Lemoine

18 to $24 \mathrm{in}$.

1.00

Double, large, white

2 to $3 \mathrm{ft}$.

1.25

Michael Buchner

18 to 24 in.

1.00

Double, pale lilac.

2 to $3 \mathrm{ft}$.

1.25

Oliver de Sierres

18 to 24 in.

Double, pale lilac-blue.

Philemon

18 to $24 \mathrm{in}$.

Dark reddish purple.

2 to $3 \mathrm{ft}$.

1.00

Pres. Faillieres

2 to $3 \mathrm{ft}$.

1.25

Double, pale lavender.

3.00

Pres. Grevy

18 to $24 \mathrm{in}$.

Double, very fine, blue.

2 to $3 \mathrm{ft}$.

1.25

Pres. Viger

18 to 24 in.

Double, fine bluish-lilac.

2 to $3 \mathrm{ft}$.

1.50

Rubra d' Marley-Double, purple

18 to 24 in.

2 to $3 \mathrm{ft}$.

Statgartner Rothpelz

18 to 24 in.

Double, reddish purple.

2 to $3 \mathrm{ft}$.

Volcan

18 to 24 in.

Single, large, ruby red. 


\section{SHRUBS-Continued}

Wm. Robinson

Size

Double, rosy lilac.

18 to $24 \mathrm{in}$.

Each

PHILADELPHUS, Mockorange; Syringa

Avalanche

Matures at $4 \mathrm{ft}$, very fragrant. 2 to $3 \mathrm{ft}$.

Banniere

2 to $3 \mathrm{ft}$.

Tall, semi-double, very early.

3 to $4 \mathrm{ft}$.

5.00

Bouquet Blanc

2 to $3 \mathrm{ft}$.

1.25

Double flowers.

3 to $\neq \mathrm{ft}$.

Coronarius, the common Mockorange 18 to $24 \mathrm{in.}$

Golden, Aurea

12 to $15 \mathrm{in}$.

Dwarf, golden leaves, compact, flowers small.

\section{5 to $18 \mathrm{in}$.}

18 to $24 \mathrm{in}$.

2 to $2 \frac{1}{2} \mathrm{ft}$.

Virginale

Very large, very fragrant, flowers

2 to $3 \mathrm{ft}$. over a long season.

PEARL BUSH, Exochordia 2 to $3 \mathrm{ft}$.

PRIVETS-See under Hedge Plants.

PRUNUS-See among Ornamental Trees.

\section{QUINCE, Cydonia japonica}

Japanese flowering, scarlet flowers early.
12 to $18 \mathrm{in.}$

18 to $24 \mathrm{in}$.

2 to $3 \mathrm{ft}$.
4.50

7.00

9.00

5.00

Tree Form

2 to $3 \mathrm{ft}$.

SNOWBERRY, Symphoricarpos

racemosus

5 to $6 \mathrm{ft}$.

18 to $24 \mathrm{in}$.

2 to $3 \mathrm{ft}$. enduring. 
SHRUBS-Continued

$\begin{array}{crrr} & \text { Size } & \text { Each } & \text { Per } 10 \\ \text { arguta } & 18 \text { to } 24 \mathrm{in.} & .60 & 5.00 \\ \text { Very early, medium size. } & 2 \text { to } 21 / 2 \mathrm{ft} & .75 & 7.00 \\ \text { billardi } & 18 \text { to } 24 \mathrm{in.} & .35 & 2.50 \\ \text { Pink flowers in spikes. } & 2 \text { to } 3 \mathrm{ft} . & .50 & 4.00 \\ \text { collosa alba, dwarf white } & 12 \text { to } 15 \mathrm{in.} & .45 & 3.50 \\ & 15 \text { to } 18 \mathrm{in.} & .60 & 5.00 \\ & 18 \text { to } 24 \mathrm{in.} & .75 & 6.50\end{array}$

froebeli, pink, dwarf

12 to 18 in.

18 to 24 in.

2 to $2 \frac{1}{2} \mathrm{ft}$.

$21 / 2$ to $3 \mathrm{ft}$.

opulifolius aurea, Physocarpus opulifolius, Golden Spirea

2 to $3 \mathrm{ft}$.

3 to $4 \mathrm{ft}$.

4 to $5 \mathrm{ft}$.

2.50

3.50

6.00

7.50

.70

3.00

.45

6.00

sorbifolia, Ash leaved Spirea Sorbaria

sorbifolia

18 to $24 \mathrm{in}$.

2 to $3 \mathrm{ft}$.

4.50

5.00

thunbergi

12 to 18 in.

Very fine foliage and twigs, early, 18 to $24 \mathrm{in.}$

3.50

white, small bush.

.50

.60

4.50

vanhoutti, Bridal Wreath

12 to $18 \mathrm{in.}$

1.50

18 to 24 in.

2.50

2 to $3 \mathrm{ft}$.

4.00

3 to $4 \mathrm{ft}$.

5.00

4 to $5 \mathrm{ft}$.

6.00

SUMAC, Rhus

18 to $24 \mathrm{in}$.

Aromatic, $R$. canadensis

2 to $3 \mathrm{ft}$.

7.00

.75

8.00

Fragrant Sumac.

.90

.40

3.50

Staghorn Cut Leaved, R. tyhina

18 to 24 in.

lacinata

2 to $3 \mathrm{ft}$.

Twigs velvety; foliage very finely cut. 3 to $4 \mathrm{ft}$.

.50

4.50

4 to $5 \mathrm{ft}$.

7.00

.75

8.00

TAMARIX

2 to $3 \mathrm{ft}$.

3.50

Foliage feathery, flowers pink.

3 to $4 \mathrm{ft}$.

5.00

VIRBURNUM-See also Snowball and

Cranberry.

carlesi

15 to 18 in.

2.50

Pinkish-white, very fragrant and rare. 18 in 24 in.

dentatum, Arrowwood

Succeeds in all locations and colors

brilliantly in fall

18 to 24 in.

2 to $3 \mathrm{ft}$.

3 to $4 \mathrm{ft}$.

lantana, Wayfaring Tree

Thick rugose foliage.

18 to 24 in.

2 to $3 \mathrm{ft}$.

18 to 24 in.

2 to $3 \mathrm{ft}$.

Rich reddish-purple.

18 to 24 in.

2 to $3 \mathrm{ft}$.
.50

.75

4.00

.90

6.00

7.50

.75

7.00

9.00

.75

7.00

1.00

9.00

.45

4.00

.60 


\section{HEDGE PLANTS}

(See also Arborvitae and Spruce under Evergreens, and Russian Mulberry under Forest Trees)

BARBERRY, Japanese, Berberis

\begin{tabular}{|c|c|c|c|c|}
\hline thunbergi. & Size & Each & Per 10 & Per 100 \\
\hline Heavy 3-year & 15 to $18 \mathrm{in.}$ & $\$ 0.35$ & $\$ 3.00$ & $\$ 25.00$ \\
\hline Heavy 3-year & 18 to $24 \mathrm{in}$. & .40 & 3.50 & 30.00 \\
\hline Heavy 3-year & 2 to $21 / 2 \mathrm{ft}$. & .50 & 4.50 & 40.00 \\
\hline Heavy 3-year & $21 / 2$ to $3 \mathrm{ft}$. & .60 & 5.50 & 50.00 \\
\hline 2-year branched & 9 to 12 in. & & 1.25 & 9.00 \\
\hline 2-year branched & 12 to $15 \mathrm{in}$. & & 2.00 & 15.00 \\
\hline Seedlings & 9 to 12 in. & & & 6.0 \\
\hline Seedlings _ _ & 12 to $15 \mathrm{in}$. & & & 7.5 \\
\hline RIVETS-Amur River North & 12 to $18 \mathrm{in.}$ & .20 & 1.50 & 10.0 \\
\hline Upright growing. & 18 to 24 in. & .25 & 2.00 & 17. \\
\hline & 2 to $3 \mathrm{ft}$. & .35 & 3.00 & 25 \\
\hline & 3 to $4 \mathrm{ft}$. & .40 & 3.50 & 3 \\
\hline Polish, European, vulgare & 12 to $18 \mathrm{in}$. & .20 & 1.50 & 10.0 \\
\hline Upright, hardy, retains its foliage & 18 to 24 in. & .25 & 2.00 & 1 \\
\hline uncolored very late. & 2 to $3 \mathrm{ft}$. & .35 & 3.00 & 25. \\
\hline & 3 to $4 \mathrm{ft}$. & .40 & 3.50 & 30. \\
\hline Ibota & 18 to $24 \mathrm{in.}$ & .30 & 2.50 & 20. \\
\hline Tall, much branched. & 2 to $3 \mathrm{ft}$. & .40 & 3.50 & \\
\hline & 3 to $4 \mathrm{ft}$. & .50 & 4.50 & 40. \\
\hline Regals, True Type & 12 to 18 in. & .30 & 2.50 & \\
\hline Low shrub, horizontal branches. & 18 to $24 \mathrm{in}$. & .40 & 3.50 & \\
\hline & 2 to $21 / 2 \mathrm{ft}$ & .50 & 4.50 & \\
\hline
\end{tabular}

\section{ROSES}

All plants offered are two-year field-grown bushes. One-half or more of the tops should be cut off and the bushes planted deeper than they stood in the Nursery.

\section{CLIMBING ROSES}

(All need winter protection except as noted)

AMERICAN PILLAR, 75c: Immense clusters; large, single; bright crimson, lighter center.

BALTIMORE BELLE, 50c: Blush-white, an old favorite, rather tender.

CRIMSON RAMBLER, 50c: Bright red, large clusters, the most popular climber.

CLIMBING AMERICAN BEAUTY, 75c: Large rich carmine, somewhat fragrant.

DR. VAN FLEET, 90c: Light pink, perfectly formed, pointed buds, long stems.

DOROTHY PERKINS, 50c: Delicate pink, large clusters, vigorous and healthy.

EXCELSA, Red Dorothy Perkins, 50c: Lighter red than Crimson Rambler, but more vigorous.

FLOWER OF FAIRFIELD, 75c: Ever-blooming crimson rambler.

HIAWATHA, 50c: Single, deep crimson with yellow center, very fragrant.

LADY DUNCAN, 75c: Pure pink, cross of Rosa Rugosa and Rosa Wichuriana.

MAX GRAF, 75c: Large, single shining pink, climbing rugosa. Excellent ground and rock cover, needs no protection.

PAUL'S SCARLET, 90c: Large, bright, pure red, semi-double, in clusters.

PRAIRIE QUEEN, 50c: Large globular, bright pink, one of the hardiest climbers. ROSA SETIGERA, 50c: The wild prairie rose, single, light pink flowers and bright red heps. 


\section{ROSES-Continued}

ROSIERE, 75c: A darker colored Thousand Beauties.

SILVER MOON, 90c: Silvery white with yellow stamens.

TAUSENDSCHON, 75c: Large elusters ranging from bright pink to pure white.

WHITE DOROTHY PERKINS, 50c: The best pure white climbing rose.

WICHURIAN, Memorial, 50c: Glossy foliage with very fragrant, creamy white flowers.

\section{HARDY ROSES}

(Varieties which need no winter protection in Central Iowa)

HARRISON YELLOW, 90c: Small bright yellow, early in spring.

HENRI MARTIN, 75c: Rosy red, mossed heavily, fragrant.

HUGONIS, \$1.25: A tall spring flowering shrub with yellowish flower.

KAMCHATKA, 75c: Bright red, double, a form of Rosa Rugosa.

MAD. PLANTIER, 50c: Pure white, almost thornless, blooms in spring only.

PERSIAN YELLOW, 90c: Deepest yellow, Austrian brier.

ROSA blanda, 75c: Single, pink, tall upright grower, good shrub.

ROSA lucida, 75c: Bright pink.

ROSA rubrifolia, 75c: A shrubby, perfectly hardy bush with reddish foliage and and pink flowers, prefers partial shade.

ROSA rugosa, 75c: Single, large bright red; wrinkled, tough foliage; continuous bloomer, very large crimson heps.

ROSA rugosa alba, 75c: White form of Rosa Rugosa.

SALET, 75c: Moss, large full rose pink.

SEVEN SISTERS, 50c: Double, large, varying from light red to white.

SWEET BRIAR, 90c: Pink flowers, fragrant foliage.

WHITE MOSS, 75c: Large, pure white, fragrant, heavily mossed.

\section{OTHER ROSES}

H. T. means Hybrid Tea; H. P. means Hybrid Perpetual. All these should have winter protection. The Baby Ramblers and H. T.'s are the most constant bloomers. AMERICAN BEAUTY, 90c: H. P., large globe shaped, crimson.

BABY RAMBLERS, 90c: Red, white, or pink; not elimbers, but dwarf bushes.

Named Varieties:

Clotilde Soupert, 90c: Very full, pearly white shaded pink.

Gruss an Aachen, \$1.00: Very large, light rose overlaid with yellow.

Jessie, 90c: Glowing crimson with white eye.

LaFayette, \$1.00: Large brilliant cherry-crimson flowers.

Orleans, 90c: Geranium red with rose tint.

CONRAD F. MEYER, 90c: Hybrid Rugosa, delicate pink, strong upright grower.

EDWARD MAWLEY, 90c: H. T., very dark velvety crimson, most fragrant.

ETOILE De FRANCE, 90c: H. T., large cupped, velvety erimson, very fragrant.

FRAU KARL DRUSCHKI, 75c: H. P., the very purest white, continuous bloomer. GEN. JACQUEMINOT, 75c: H. P., scarlet-crimson, early and fragrant.

GEN. McARTHUR, 90c: H. T., sweetly scented, brilliant crimson scarlet, very free bloomer.

GEO. ARENDS, 90c: H. P., large, fragrant, pink, called “Pink Druschki.",

GOLDEN OPHELIA, \$1.00: H. T., a golden form of the Ophelia variety.

GROOTENDORST, 90c: Hybrid Rugosa X, Baby Rambler; semi-double, bright red.

GRUSS AN TEPLITZ, 90c: H. T., clear crimson-scarlet, the most continuous bloomer.

J. B. CLARK, 75c: H. P., very large, intense scarlet; vigorous grower. 


\section{ROSES-Continued}

JOHN HOPPER, 75c: H. P., large, rosy red, fragrant, medium grower.

LADY HILLINGTON, 90c: H. T., long pointed buds opening apricot yellow. IOLITA ARMOUR, \$1.00: Pernetiana, large, fragrant, chrome-yellow at base shading to bright salmon.

IOS ANGELES, \$1.25: H. T., coral pink shaded coppery gold, moderately hardy. MAGNA CHARTA, 75c: H. P., very large, rosy pink, tinted carmine. MRS. JOHN LAING, 75c: Large, soft pink, pointed buds, vigorous grower. MME. BUTTERFLY, 90c: H. T., a more brilliant Ophelia.

OPHELIA, 90c: H. T., salmon-flesh, fragrant, long stems, very productive. PAUL NEYRON, 75c: H. P., rery largest, clear pink, fragrant, thornless.

PRINCE CAMILLE De ROHAN, 75c: H. P., dark blood red, large, fragrant, rather weak grower.

RADIANCE, 90c: H. T., fine salmon pink, long stems, very productive. RED RADIANCE, 90c: H. T., deep red, finest form, extremely productive. ROSE MARIE, 90c: H. T., rose pink.

SUNBURST, 90c: H. T., bright orange yellow, with paler edge.

SOLEIL D' OR, 90c: Orange yellow rarying to ruddy gold, not continuous. SOUV. D' CLAUDIUS PERNET, \$1.25: H. T., deep yellow.

ULRICH BRUNER, 75c: H. P., large, fragrant, cherry red, rigorous.

\section{CLIMBING VINES}

AMELOPSIS, IVy

(Two-year No. 1 plants except as noted)

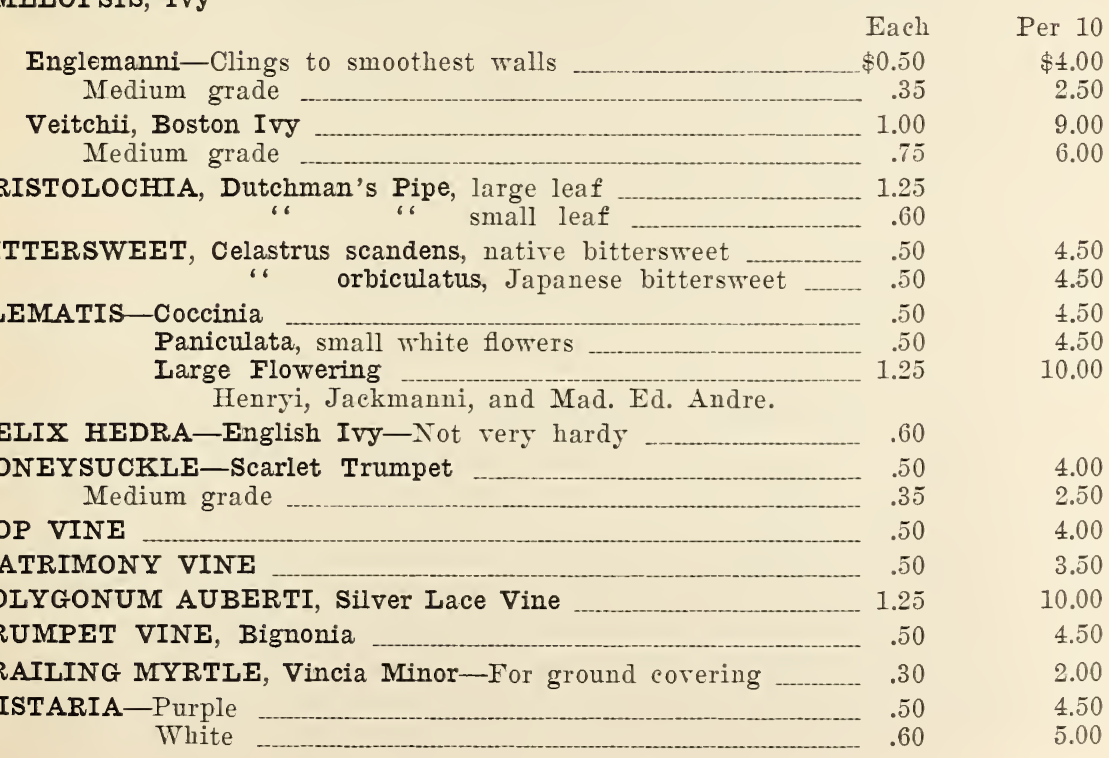




\section{PEONIES}

We do not keep a stock of the more expensive varieties in storage for spring planting, so any order for them will be held till fall, which is the very best time to plant peonies.

Prices are for standard divisions of 3 to 5 eyes or buds. Undivided clumps figured on this basis.

ASA GRAY, \$1.00: Semi-rose type, mid-season, pink with carmine dots.

ADOLPHE ROSSEAU, \$1.50: Semi-double, early, brilliant red.

AGNES M. KELWAY, 40c: Crown type, early, pale rose with ereamy center.

AVALANCHE, \$1.00: Crown type, late, very fine milk white.

AUGUSTIN D'HOUR, 75c: Bomb type, tall, mid-season, rich scarlet purple.

BARONESS SCHROEDER, \$1.25: Rose type, late, flesh color fading white.

COUROUNE D' OR, 50c: Semi-rose type, late, white with yellow stamens.

CLAIRE DUBOIS, \$1.00: Rose type, tall, late, fine pink with glossy reflex.

DELACHEI, 75c: Rose type, late, brilliant dark maroon.

DENIS HELYE, 50c: Semi-rose type, mid-season, brilliant red.

EDULIS SUPERBA, 50c: Crown type, very early bright pink.

ENCHANTRESSE, \$5.00: Rose type, very late, creamy white.

ELWOOD PLEAS, \$4.00: Rose type, late mid-season, tall, light shell-pink.

FESTIVA MAXIMA, 50c: Rose type, early, pure white, tipped carmine.

FRANCOISE ORTEGAT, 75c: Semi-rose type, mid-season; deep crimson.

FELIX CROUSSE, 75c: Rose type, late mid-season, bright ruby red.

FRAGRANS, 40c: Bomb type, mid-season, deep pink.

GOLDEN HARVEST, 40c: Bomb type, mid-season, pink, creamy white center.

GRANDIFLORA, 50c: Rose type, late, very fine bright pink.

GROVER CLEVELAND, \$1.00: Rose type, late, large, dark crimson.

H. F. REDD|ICK, $\$ 1.00$ : Semi-rose type, nid-season, brilliant crimson.

JENNY LIND, \$1.00: Bomb type, tall, mid-season, light pink interspersed with white.

JUBILEE, \$4.00: Rose type, very tall, white with delicate pink center.

KARL ROSENFIELD, \$1.25: Semi-rose type, mid-season, rich blood red.

LE CYGNE, \$15.00: Rose type, pure white, has the very highest rating.

LADY ALEXANDER DUFF, \$3.50: Rose type, early, pink fading white.

LATULIP, 50c: Semi-rose type, flesh pink fading white, red markings.

L' ESPERANCE, 50c: Rose type, very early, rose pink.

LIVINGSTONE, 75c: Rose type, late, deep pink, fine cut flower.

LONGFELLOW, \$5.00: Semi-rose type, the most brilliant red.

LOUIS VAN HOUTTI, 75c: Semi-rose type, bright violaceaus red.

MARIE LEMOINE, \$1.00: Rose type, very late, ivory white.

MARTHA BULLOCK, $\$ 10.00$ : Rose type, tall, very large, rosy pink.

- MAD. CHAUMY, 40c: Rose type, very late, bright rose.

MARECHAL VALIIANT, 50c: Rose type, very large, late, purplish red.

MIREILLE, \$1.00: Rose type, very late, milk white.

MAD. DE VERNEVILLE, 50c: Bomb type, mid-season, white, very choice.

MAD. EMILE GALLE, \$1.00: Rose type, late, pale pink, shaded lilac-rose.

MON. JULES ELIE, \$1.00: Bomb type, mid-season, glossy pink, extra fine.

MONS. MARTIN CAHUZAC, \$2.50: Semi-rose type, early, darkest deep maroon.

MODISTE GUERIN, 75c: Bomb type, mid-season, deep lustrous pink.

OFFICINAIIS RUBRA PLENA, \$1.00: Very earliest, bright crimson. 


\section{PEONIES-Continued}

OFFICINAIIS ROSEA, \$1.00: Tery earliest, rose pink. OFFICINALIS TENUIFOLIA, \$1.50: Fern leaved, very earliest, bright crimson. PASTEUR, \$2.00: Rose type, mid-season, very soft pink. PRES. ROOSEVELT, \$1.00: Semi-rose type, mid-season, deep red. PRIMEVERE, \$3.00: Bomb type, mid-season, tall, creamy yellow. RACHEL, \$1.00: Rose type, mid-season, brightest ruby red. RICHARD CARVEL, \$4.00: Bomb type, early, very bright crimson. ROSA BONHEUR, \$4.50: Rose type, dwarf, light violet rose flecked crimson. RUBRA TRIUMPHANS, 50c: Semi-double, early, red with yellow stamens. SOLANCE, \$4.00: Rose type, mid-season, white shaded salmon. THERESE, \$4.50: Rose type, mid-season, delicate satiny pink. TOURANGELLE, \$5.00: Rose type, late, creamy buff with salmon tints.

WALTER FAXSON, \$5.00: Semi-rose type, mid-season, distinct bright salmon rose.

\section{SINGLE AND JAPANESE VARIETIES}

AKALU, \$2.00: Japanese, carmine red with center saffron yellow, striped carmine. ANOMALE, \$2.00: Single, bright red, very earliest. GERALDINE, \$1.50: Japanese, deep carmine violet. KING OF ENGLAND, \$4.00: Japanese, rich ruby-red with narrow golden center petals.

MIKADO, \$1.50: Japanese, dark crimson with center crimson, tipped gold.

OFFICINALIS TENUIFOLIA ROSEA, \$1.00: Single, pink.

PETITE RENEE, 75c: Japanese, light magenta.

SNOW WHEEL, \$4.00: Japanese, pure white throughout.

STANLEY, \$1.00: Single, large, dark brilliant erimson.

SINGLE RED, 50c: Unnamed, very early.

THE BRIDE, \$1.00: Single, large, white with yellow center.

\section{PHLOX}

CHAMPS ELYSEE, purplish erimson

Each $\$ 0.30$

CAMP'S ELYSEE, purplish crimson $\$ 0.30$

DIVARTICA LAPHAM, Blue Canadian, improved ECLAIREIEUR, magenta

H. O. WIDGER, white with large crimson eye

JULES SANDEAU, large delicate salmon pink

MISS LINGUARD, very early, pure white

MRS. JENKINS, large, white

R. P. STRUTHERS, cherry red with claret red eye.

RYNSTROM, bright carmine rose

SUBLATA, Pink, White, Lilac, or Vivid, creeping
Per 10

$\$ 2.50$

$\$ 2.50$

2.50

2.50

2.50

2.50

2.50

2.50

2.50

2.50

2.50 


\section{IRIS}

Iris may be planted almost any time, but preferably not at or just previous to blooming time. Iris should be planted very shallow and on dry, well drained soil, except the Siberian varieties and other fibrous rooted kinds, which are moistureenduring. The effect is better if a group of one kind or color is planted rather than single plants of many colors.

\section{Quantity Rates. Kinds priced at:}

$10 \mathrm{c}$ each are $\$ 0.60$ per 10 and $\$ 4.00$ per 100

$15 \mathrm{c}$ each are .80 per 10 and 6.00 per 100

$20 \mathrm{e}$ each are 1.00 per 10 and 8.00 per 100

$25 \mathrm{c}$ each are 1.50 per 10 and 12.00 per 100

S. denotes standards, the upright part of the flower; and $F$, falls.

DWARF IRIS, 5 to 12 inches high, very early, fine for borders.

Cyanea, 10c: S., rich blue; F., dark satiny purple, 6 inches high.

Schneekuppe, 30c: S. and F., pure white, 6 to 10 inches, very fine.

Excelsa, 20c: S. and F., deep clear yellow, 8 inches.

INTERMEDIATE IRIS: Intermediate in height and season of blooming.

Helge, 15c: S. and F., lemon yellow with pearl shadings, large.

Ingeborg, 25c: S. and F., very fine large pure white.

Walhalla, 15c: S., light blue; F., velvety violet purple.

Maori King, 25c: S., richest golden yellow; F., velvety maroon.

\section{TALL BEARDED IRIS:}

Afterglow, 60c: S. and F., delicate greyish pink shaded yellow.

Ambassador, \$1.00: S., smoky reddish violet; F., dark velvety maroon.

Archeveque, 40c: S., deep violet purple; F., rich velvety violet.

Blue Jay, 40c: S., clear blue; F., dark blue.

Celeste, 30c: S. and F., clear azure blue.

Dalila, 50c: S., coppery bronze; F., velvety erimson.

Darius, 20c: S., canary yellow; F., lilac margined white.

Dr. Bernice, 20c: S., coppery bronze; F., velvety crimson.

Flavescens, 15c: S. and F., pale sulphur yellow, sweetly scented.

Gypsy Queen, 15c: S., old gold shaded pearl; F., reticulated maroon.

Her Majesty, 30c: S. and F., rose pink.

Hiawatha, 30c: S., pale lavender; F., royal purple.

Honorabilis, 10c: S., golden yellow; F., brownish mahogany.

Johan de Witte, 10c: S., bluish violet; F., deep violet veined white.

Juniata, 25c: S., arching; F., flaring, clear blue throughout.

Kermesiana, 15c: Claret red, marked, medium size, endures moisture.

Kochi, 15c: S. and F., rich blackish purple, very large and fine.

Latendresse, 10c: S. and F., ageratum blue throughout.

Lent A. Williamson, \$1.00: S., lavender violet; F., royal purple.

Loreley, 20c; S., light yellow; F., blue bordered cream.

Mariposa, \$1.00: S., French gray; $F$., flaked purple.

Mary Garden, 30c: S., pale yellow flushed lavender; F., creamy dotted.

Mad. Chereau, 10c: S. and F., white, frilled pale blue, tall and late.

Midwest, \$1.25: S. and F., ruffled, dotted, and blushed rose on a white ground.

Mother of Pearl, $\$ 1.50$ : S. and F., pale bluish lavender, delicately tinted.

Monsignor, 30c: S., deep violet; F., purplish crimson, veined darker.

Mrs. H. Darwin, 15c: S. and F., pure white with purplish veins. 


\section{IRIS-Continued}

Nibelungen, 30c: S., famn; F., violet purple, reined purple. Nokomis, 30c: S., pale lavender white; F., deep violet blue. Pallida Delmatica, 25c: S. and F., light larender violet. Pallida Speciosa, 20c: S., dark lavender; F., light purple. Parc de Neuilly, 30c: S. and F., rich plum purple, large. Perfection, 30c: S., light blue; F., dark violet.

Princess Beatrice, 50c: A selected rariety of Pallida Delmatica.

Princess Victoria Louise, 25c: S., sulphur yellow; F., rich plum bordered eream. Prosper Laugier, 30c: S., light bronze red; F., velvety Bordeaux.

Quaker Lady, 40c: S., smoky lavender; F., ageratum blue and old gold.

Queen Alexandria, 25c: S., fawn orercast lilac; F., lilac.

Queen of the Gypsies, 10c: S., bronze; F., purplish red.

Rheine Nixe, 25c: S., clear white; F., violet blue, edged white.

Shekinah, \$1.00: S. and F., beautiful soft yellow, tall.

Sherwin Wright, 30c: S. and F., golden yellow.

Silver King, Florentina, 15c: S. and F., white slightly tinted lavender.

Souvenier De Mme. Gandichau, \$2.00: S. and F., brilliant black purple.

Swatara, 50c: S., lobelia blue suffused yellow; F., violet.

White Knight, $75 \mathrm{c}$ : S. and F., pure white, late.

Zua, 75c: S. and F., delicate lavender white, ruffled like fine crepe.

\section{SIBERIAN AND OTHER IRIS:}

Blue King, 15c: Siberian, clear blue with rery delicate markings.

Cristata, 40c: Creeping, 3 in., rich blue, for the rockery.

Dichotoma, Vesper Iris, 40c: 2 to $3 \mathrm{ft}$., much branched stems, light lavender flowers in afternoons for four weeks in August or September.

Geo. Wallace, 30c: Siberian, S., azure blue; F., marked white.

Longipetala Superba, 30c: Dainty lavender.

Lord Woolsey, 40c: Very tall, large, deep purple.

Mahogany, 40c: Japanese, dark red.

Orientalis, 15c: Siberian, similar to Blue King, but a little darker.

Orientalis Gigantea, 50c: Irory white, very tall.

Pseudacorus, 30c: Wild, yellow, for the waterside.

Snow Queen, 15c: Siberian, irory white with yellowish throat.

\section{OTHER HARDY PERENNIALS}

The measure given is the height they grow, and the dates, the blooming period. Most perennials can be moved well either fall or spring, and many of them through the summer. Prices, unless otherwise giren: Field-grown plants, $30 \mathrm{e}$ each, $\$ 2.40$ per dozen, $\$ 15.00$ per $100-3$ or more at dozen rates, and 25 or more at hundred rates.

ACHILLEA, Milfoil or Yarrow

The Pearl, $1 \mathrm{ft}$., pure white, all summer.

AGROSTEMMA, Rose Champion or Mullein Pink-21/2 ft., June-July. Silvery foliage and bright crimson flowers.

ALLYSSUM Saxitile, Basket of Gold-1 ft., bright yellow, early spring, fine for rockery or borders.

ANTHEMUS, Marguerite—2 ft., large golden yellow flowers, all summer.

ARABIS alpina, Rock Cress-1 ft., early, masses of white flowers, fine for rockery or border. 


\section{OTHER HARDY PERENNIALS-Continued}

ASCLEPIAS tuberosa, Butterfly Weed-21/2 ft., July-August, bright orange flowers in umbels.

ASTILBE arendsi, Rose Pearl-2 to $3 \mathrm{ft}$., June-July, bright pink.

AUBRETIA, Rock Cress-Creeping, bluish flowers, in early spring.

BLEEDING HEART, 60c: Dicentra Spectabilis-1 to $2 \frac{1}{2} \mathrm{ft}$., early, shade-enduring. BLEEDING HEART, FERN LEAVED, 50c: Dicentra Eximia-Dwarf, everblooming, finely cut foliage, splendid for rockery.

BOLTONIA asteroides-5 to $6 \mathrm{ft}$., September, white aster-like flowers.

CAMPANULA, Bellflower

Carpatica, Harebell--8 in., clear blue, June to October.

CENTRANTHUS ruber-11/2 ft., June-October, red flowers in heads.

CENTUREA montana-2 ft., July-September, large violet blue flowers in heads. CHRYSANTHEMUMS-Hardy

$\begin{array}{cc}\text { Carmelite, golden yellow, September and October. } \\ \text { Old-Fashioned-Pink } & \text { October and November. } \\ \text { White } & \text { October and November. } \\ \text { Yellow } & \text { October and November. }\end{array}$

CLEMATIS recta -2 to $3 \mathrm{ft}$., June-July, fragrant small white flowers in clusters.

$\begin{array}{ll}\text { COLUMBINES, Aquilegia-White } & 2 \mathrm{ft.} \text { - early spring. } \\ \text { Coerulea } & 2 \mathrm{ft} \text {, blue shades. } \\ \text { Common American } & 2 \mathrm{ft} . \text { red and yellow. } \\ \text { Long spurred hybrids } & \text { Mixed colors. }\end{array}$

DAISY-Giant, 3 to $4 \mathrm{ft}$., July to September.

Double White Shasta, 12 to 18 in., all summer.

Shasta, 1 to $2 \mathrm{ft}$., September and October.

DELPHINIUM, Larkspur

Belladonna, 3 to $4 \mathrm{ft}$, light blue, all summer.

Bellamosa, 3 to $4 \mathrm{ft}$., dark blue, all summer.

Chinese Blue, 2 ft., finely cut foliage, gentian blue, all summer.

Chinese White, 2 ft., finely cut foliage, white, all summer.

DIANTHUS

Gold Medal Hybrids, $4 \mathrm{ft}$. or more, mixed colors, all summer.

Barbatus, Sweet William, $1 \mathrm{ft}$, mixed colors, in early summer.

Latifolius, $1 \mathrm{ft}$. , brilliant red flowers, all season.

Plumarius, Clove Pinks, mixed colors, dwarf, grasslike foliage, early spring.

ENGLISH BUTTERCUP, Ranunculus, $1 \mathrm{ft}$, double, bright golden yellow flowers in May or June.

FILIPENDULA ulmaria, Meadowsweet, 2 ft., July, creamy white in feathery plumes.

FUNKIA, BLUE DAY LILY, PLANTAIN LILY

Coerulea, 11/2 ft., July, blue drooping flowers.

Subcordata Grandiflora, 40c: 3ft., $\Lambda$ ugust-September, white fragrant.

GAILLARDIA, 1 to $2 \mathrm{ft}$., all summer, red, yellow, and orange blended.

GOLDEN GLOW, 4 to 6 ft., August, large golden yellow flowers.

GYPSOPHYLLA, Baby's Breath, 2 to $3 \mathrm{ft}$., fine white flowers in late summer.

HEMEROCALLIS, Yellow Day Lily

Flava, Lemon Lily, 21/2 ft., May and June, clear yellow.

Fulva, Tawny Lily, 3 to 5 ft., coppery orange and crimson, July.

Thunbergii, 2 ft., yellow, July.

Florham, 40c: 3 to $3 \frac{1}{2} \mathrm{ft}$., very large, rich yellow, July.

Gold Dust, 2 to $3 \mathrm{ft}$., July, very rich yellow.

Kwanso, 3 to $4 \mathrm{ft}$., double, golden bronze, July. 


\section{OTHER HARDY PERENNIALS-Continued}

HIBISCUS, 4 to $5 \mathrm{ft}$., clear rose colored, 6 in. flowers, July to September.

HOLLYHOCKS, assorted colors, 4 to $7 \mathrm{ft}$, August and September.

IBERIS sempervirens, dwarf, white, early spring, splendid for edging on rockery. rockery.

INCARVILLEA

Hardy Gloxinia, 11/2 ft., large rose pink flowers, through summer.

LILIUM, Lilies, all blooming sized bulbs.

elegans, 30c: Early, upright, orange blossoms.

regal, 75c: White shaded pink, fragrant.

speciosum magnificum, 50c: Tall, pink with erimson dots.

superbum, Turk's Cap, 30c: Orange, tipped red.

tigrinum, Tiger, 30c: One of the commonest varieties.

LINUM, Hardy Flax, 1 to $2 \mathrm{ft}$, blue, all summer.

MYOSOTIS, Forget-Me-Not, dwarf, blue, early summer.

OENOTHERA youngi, Sundrops, Evening-Primrose, $2 \mathrm{ft.,} \mathrm{June} \mathrm{to} \mathrm{August,} \mathrm{bright}$ lemon yellow.

PENSTEMON barbatus, $3 \mathrm{ft}$., June to August, bright scarlet.

PHYSOSTEGIA, False Dragonhead

Virginica, 3 to $4 \mathrm{ft}$., July-August, spikes of delicate pink.

Virginica Alba, a white form of the abore.

PLATYCODON, Balloon Flower

Grandiflora, 2 ft., June to October, large blue or white bell shaped flowers.

Mariesi, 12 to 15 in., otherwise like abore.

POPPY-Iceland, 1 to 2 ft., mostly yellow.

Oriental, 2 ft., large scarlet flowers, centers black, June, transplant in August.

PYRETHRUM, Persian or Painted Daisy

Hybridum, 2 to $3 \mathrm{ft}$, pink and white, May to July.

Atrosanguinea, dark shades of the abore.

SALVIA turkestanica, $3 \mathrm{ft}$, large decorative wooly leaves, small white flowers.

SAPONARIA, Soapwort, dwarf, small rosy flowers, in early summer.

SCABIOSA caucasica, Blue bonnet, 2 ft., lavender flowers, all summer.

STATICE latifolia, Sea Lavender, 1 to $2 \mathrm{ft}$., small purplish blue flowers, broad thick leares.

STOKES ASTER, 1 to $2 \mathrm{ft.,} \mathrm{large} \mathrm{larender} \mathrm{blue} \mathrm{flowers,} \mathrm{July} \mathrm{to} \mathrm{October.}$

STONE CROP, Sedum or Live Forever

Anglicum, 2 in., forms a bluish green mat.

Coccinea, 6 to 8 in., red flowers.

Kamchaticum, 6 in., bright light green, rellow flowers.

Rupestre, 4 to 6 in., reddish stems.

Sieboldi, Japanese, 6 in., bright pink, September.

THALICTRUM

Spectabile, 1 to 2 ft., bright pink, August and September.

Adiantifolium, 40c: 1 to $2 \mathrm{ft}$, vellowish, June and July.

Glaucum, 40c: 1 to $2 \mathrm{ft}$, pale yellow, July and August.

TUNICA saxifraga, low tufted, small pink flowers, all summer.

VERBASCUM HARKNESS HYBRIDS, 3 to $5 \mathrm{ft}$., July-August, spikes of deep rellow flowers.

DERONICA, Speedwell

Amethystina, 1 ft., June-July, spikes of amethyst-blue flowers.

Longifolia, $2 \mathrm{ft}$., deep blue, July till frost.

Spicata, 2 ft., deep blue, June.

Teucrium, dwarf, May-June, blue.

VIOLA hybrida Haslemere, dwarf, lilac-pink flowers, continuously.

Osborn White, a pure white. 


\section{FOREST TREE SEEDLINGS}

\begin{tabular}{|c|c|c|c|}
\hline Green Ash and Soft Maple & $\begin{array}{l}\text { Size } \\
18 \text { to } 24 \mathrm{in.} \\
12 \text { to } 18 \mathrm{in} .\end{array}$ & $\begin{array}{r}\text { Per } 100 \\
\$ 3.00 \\
2.25\end{array}$ & $\begin{array}{r}\text { Per } 1,000 \\
\$ 25.00 \\
20.00\end{array}$ \\
\hline Black Locust & $\begin{array}{l}2 \text { to } 3 \mathrm{ft} . \\
18 \text { to } 24 \mathrm{in} . \\
12 \text { to } 18 \mathrm{in} .\end{array}$ & $\begin{array}{l}2.50 \\
2.00 \\
1.50\end{array}$ & $\begin{array}{l}22.00 \\
18.00 \\
12.50\end{array}$ \\
\hline Black Walnut & $\begin{aligned} 12 & \text { to } 18 \mathrm{in} . \\
6 & \text { to } 12 \mathrm{in} .\end{aligned}$ & $\begin{array}{l}6.00 \\
4.00\end{array}$ & $\begin{array}{l}50.00 \\
35.00\end{array}$ \\
\hline $\begin{array}{l}\text { Carolina Poplars, 1-year whips } \\
\text { Rooted Cuttings. }\end{array}$ & $\begin{array}{l}5 \mathrm{ft} \text { and up } \\
4 \text { to } 5 \mathrm{ft} \text {. } \\
3 \text { to } 4 \mathrm{ft} . \\
2 \text { to } 3 \mathrm{ft} \text {. }\end{array}$ & $\begin{array}{l}8.00 \\
7.00 \\
6.00 \\
4.50\end{array}$ & $\begin{array}{l}75.00 \\
60.00 \\
50.00 \\
40.00\end{array}$ \\
\hline Hardy Catalpa & $\begin{aligned} 12 & \text { to } 18 \mathrm{in} . \\
6 & \text { to } 12 \mathrm{in} .\end{aligned}$ & $\begin{array}{l}1.50 \\
1.00\end{array}$ & $\begin{array}{r}14.00 \\
8.00\end{array}$ \\
\hline Honey Locust & $\begin{array}{l}18 \text { to } 24 \mathrm{in.} \\
12 \text { to } 18 \mathrm{in.}\end{array}$ & $\begin{array}{l}2.50 \\
2.00\end{array}$ & $\begin{array}{l}22.50 \\
17.50\end{array}$ \\
\hline Russian Mulberry & $\begin{array}{r}2 \text { to } 3 \mathrm{ft} . \\
18 \text { to } 24 \mathrm{in} . \\
12 \text { to } 18 \mathrm{in} .\end{array}$ & $\begin{array}{l}3.50 \\
2.50 \\
2.00\end{array}$ & $\begin{array}{l}30.00 \\
22.50 \\
16.00\end{array}$ \\
\hline
\end{tabular}

BLACK WALNUTS HICKORIES PECANS HICANS CHESTNUTS

\section{GRAFTED NUT TREES}

The stock of all these ready for sale the spring of 1927 is all or very nearly all sold at this time and a list of any which are still available will be sent those asking for it.

The demand for them will greatly exceed the supply for some time because of the limited number of stocks which will be ready to graft, it taking from three to eight years for them to attain sufficient size.

Scions of many of them can be furnished those who have seedling trees of proper size for grafting or budding. Write concerning what you want.

WINKLER HAZLENUT. For the first time we are able to offer plants of this very large American hazlenut. The bush is of medium height, shapely, and makes a very beautiful shrub. The foliage is good, retained late and colors nicely.

Bushes such as we describe as bearing size have produced one-half pint of nuts the same season transplanted.

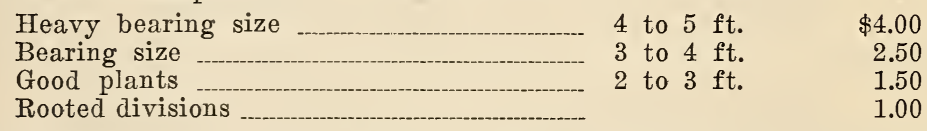

FILBERTS have not been sufficiently tested that they can be recommended for general planting, but a number of kinds are very hardy and we can furnish plants of them at $\$ 1.50$ each or $\$ 12.50$ per 10 . 


\section{ORDER SHEET}

Date

SNYDER BROS., Inc..

Limn County Nurseries,

Center Point, Iowa.

Ship to

Postoffice

County

Shipping Point

State

$\mathrm{By}$

(Freight, Express, or Parcel Post)

When

Remittance enclosed, \$

In case the size ordered is exhausted. may another size be substituted and the balance in price refunded?

In case a variety ordered is exhausted, may a similar variety be substituted?

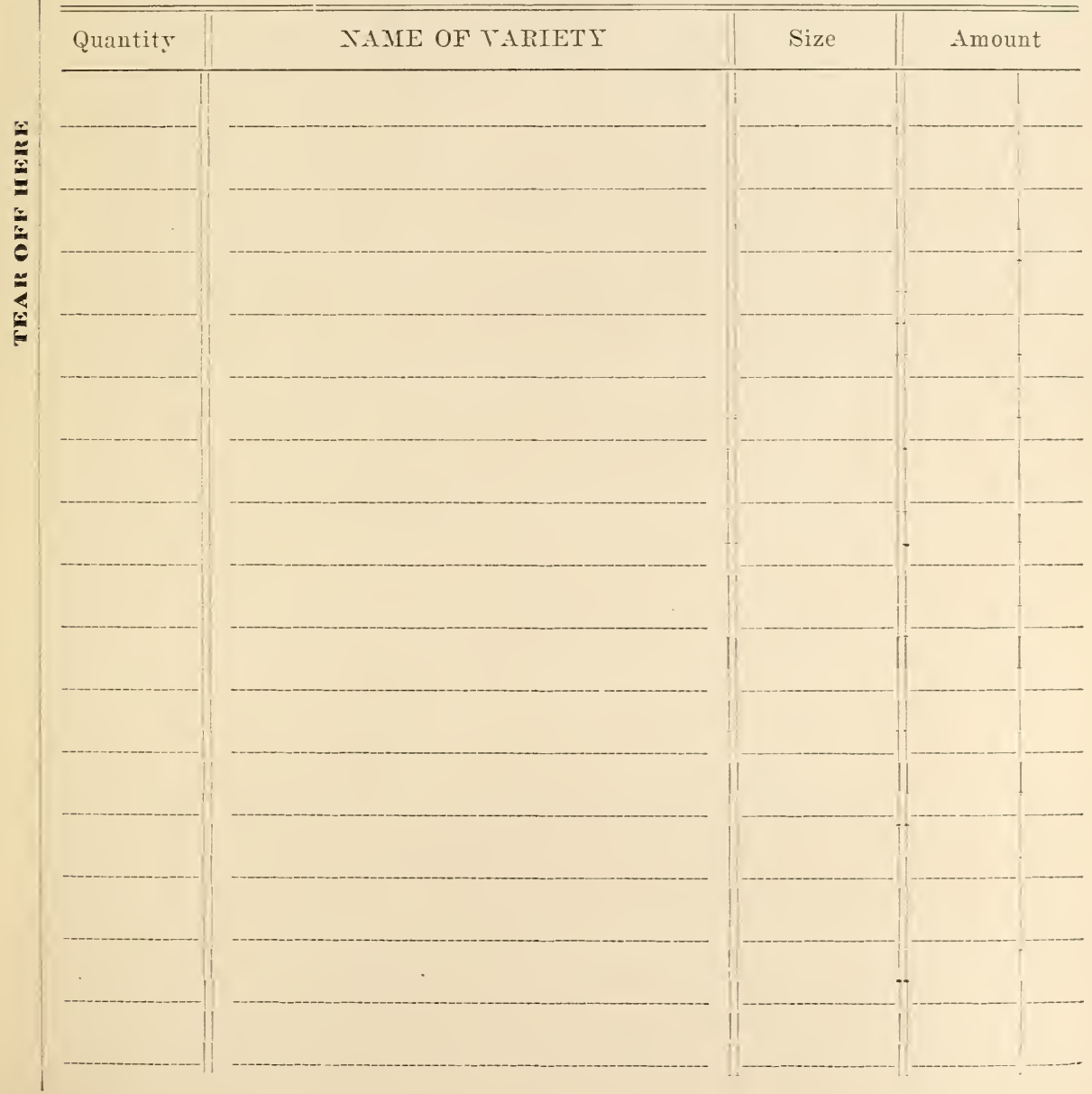




